\title{
A Rare Complication of Ventriculoperitoneal Shunt: Asymptomatic Small Bowel Perforation
}

\section{Ventriküloperitoneal Șantın Nadir Bir Komplikasyonu: Asemptomatik İnce Barsak Perforasyonu}
(D) Ünal Bakal11, (D) Ahmet Kürșad Poyraz², (D) Tugay Tartar¹, (D) Ibrahim Akdeniz¹, (D) Mehmet Beșir Sürme ${ }^{3}$, (D) Semih Çelik³, (D) Mehmet Saraç1

${ }^{1}$ FIrat University Faculty of Medicine, Department of Pediatric Surgery, Elazı̆̆, Turkey

2Firat University Faculty of Medicine, Department of Radiology Elazığ, Turkey

${ }^{3}$ Firat University Faculty of Medicine, Department of Neurosurgery, Elazığ, Turkey

\begin{abstract}
A ventriculoperitoneal (VP) shunt is a standard treatment option for the treatment of hydrocephalus. Small bowel perforation is a rare complication of VP shunt placement. We describe a case and image findings of a 15-year-old male with VP shunt who had an asymptomatic small bowel perforation. He had a history of constipation and occasional abdominal pain. The imaging findings were confirmed surgically. The results of abdominal complications of VP shunts are excellent when diagnosed and treated early. Mortality and morbidity decrease significantly with early diagnosis and treatment, especially in asymptomatic bowel perforations. We also provide an overview of the current literature discussing previously reported cases, clinical features, and treatment.
\end{abstract}

Keywords: Small bowel perforation, VP shunt surgery, VP shunt complications
ÖZ

Ventriküloperitoneal (VP) şant hidrosefalinin tedavisinde sık kullanılan bir tedavi seçeneğidir. Ince barsak perforasyonu VP şantın nadir bir komplikasyonudur. Çalışmamızda asemptomatik ince barsak perforasyonu olan 15 yaşındaki VP şantlı hastayı ve radyolojik bulgularını tanımladık. Olgunun kabızlık ve ara ara olan karın ağrısı öyküsü vardı. Görüntüleme bulguları cerrahi olarak doğrulandı. VP şantların abdominal komplikasyonlarının sonuçları erken teşhis ve tedavi edildiğinde mükemmeldir. Özellikle asemptomatik barsak perforasyonlarında erken tanı ve tedavi ile mortalite ve morbidite önemli ölçüde azalmaktadır.

Anahtar Kelimeler: Ince barsak perforasyonu, VP şant cerrahisi, VP șant komplikasyonları

\section{Introduction}

Ventriculoperitoneal (VP) shunt is a standard treatment option for the treatment of hydrocephalus. Early or late complications of VP shunt can be classified as mechanical, infectious, and functional. A rare mechanical complication of VP shunt is the migration of the catheter into the thoracic cavity, heart, bladder, hernia sacs, anus, and the distal portion of the scrotum causing infection and/or inadequate drainage of the cerebrospinal fluid (CSF). These complications may remain asymptomatic or sometimes cause mortality (1). In this report, we present a case with a VP shunt who had an asymptomatic small bowel perforation (terminal ileum) with an early and adequately description.

\section{Case Report}

Verbal and written informed consent were obtained from the patient who participated in this study. A 15-year-old male with a previous VP shunting due to meningomyelocele and hydrocephalus was evaluated because of abdominal pain and nausea. He had a history of constipation and occasional abdominal pain. Neurological and general physical examination was normal on physical examination. There was no fever, bowel sounds were normal, and there was no tenderness in the abdomen. Only white blood cell count (10:98 10e3/PL) and C-reactive protein (101 $\mathrm{Mmg} / \mathrm{L}$ ) were higher, and other parameters were normal in laboratory findings. There was no shunt dysfunction on the cranial computed tomography (CT) scan. An abdominal CT scan revealed a hyperdense catheter in the subcutaneous adipose tissue on the right abdominal 
lateral wall entering into the abdomen from the subcostal region. The catheter was lying within the right paracolic region, and the distal portion was seen inside the terminal ileum (Figure 1, 2). There was no free fluid or mesenteric fat tissue edema around the catheter. In operation, the shunt catheter tip perforating the terminal ileum was seen. There was a fibrotic tract around the catheter that did not allow fistula formation. The tract was opened, and the catheter was withdrawn. CSF flow within the catheter was seen. The peritoneal catheter was changed because of contamination. CSF microscopy and biochemistry were normal during surgery. Ventricular end and shunt valve protected because there was no central nervous system infection findings. The opening in the small intestine was closed by ligation from the tract around the entrance of the catheter. Two days after the operation, oral intake was started, and the patient was followed for eight months without any problem.

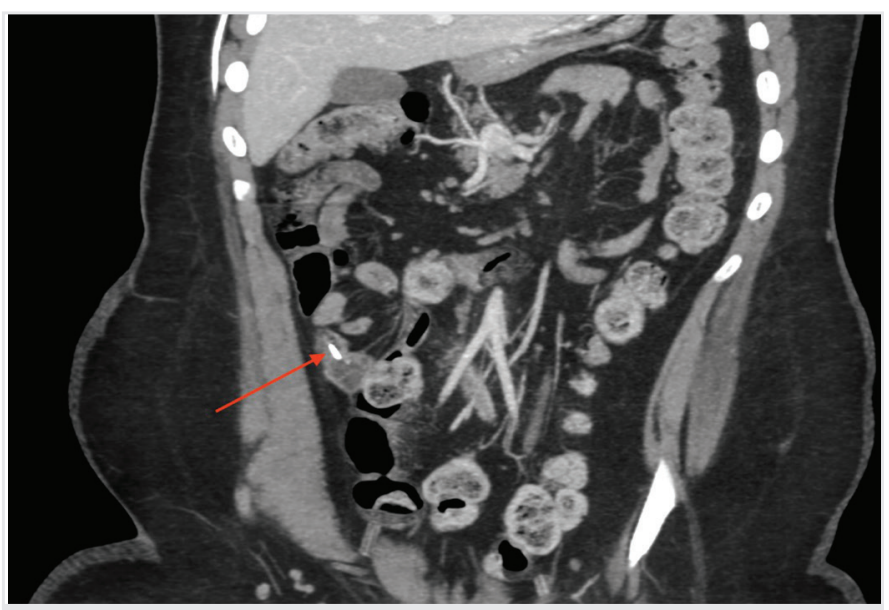

Figure 1. Ventriculoperitoneal shunt catheter appears to be in the terminal ileum in the coronal reformatted abdominal CT

CT: computed tomography

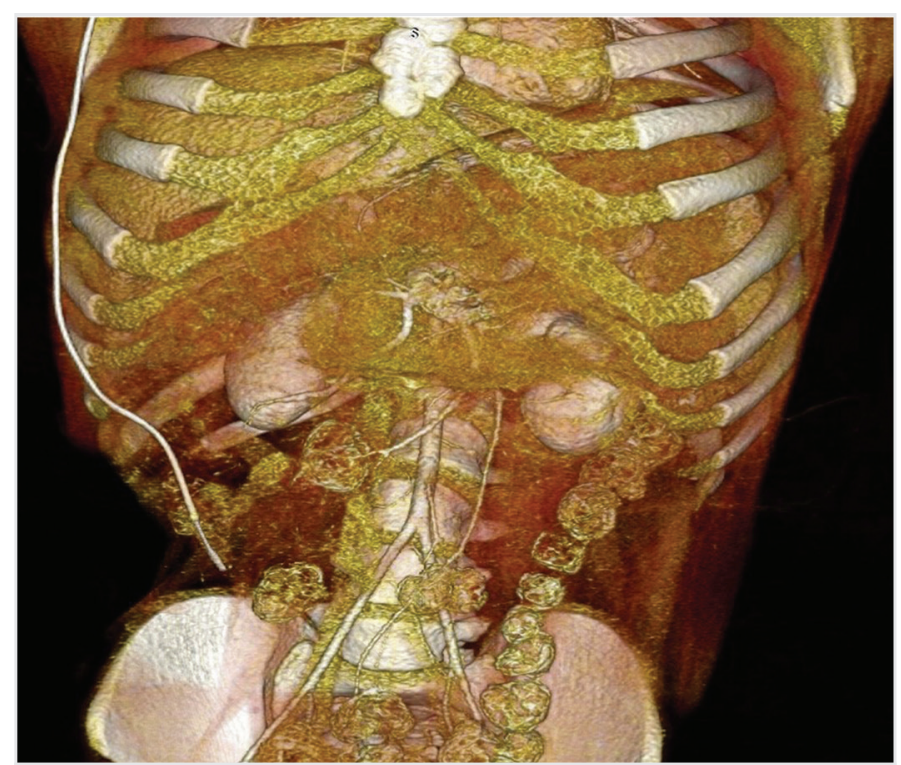

Figure 2. 3D VR image shows the catheter advancing in the right lateral wall of the chest and entering from the subcostal region into the abdomen VR: virtual reality

\section{Discussion}

The incidence of VP shunt-related complications has been reported to be $24-47 \%$, and the majority of these are late complications (2). Approximately one-fourth of these complications are intestinal volvulus, peritoneal pseudocyst, catheter penetration to the visceral organs, or protrusion through rectum, vagina, or urethra. Sometimes it can also penetrate the abdominal wall (3-5).

The incidence of perforation of the colon due to VP shunt in the gastrointestinal tract is reported to be between $0.1-0.7 \%$. After the first case of Wilson and Bertran (6), more than 70 cases have been reported. Half of the cases were asymptomatic. It has been reported that VP shunt dysfunction or protrusion of the catheter tip from the natural orifices provides the diagnosis in symptomatic cases. Up to 70\% of cases have been reported in children (1). The perforation mechanism is unclear. However, some possible mechanisms have been put forward. The main factor in perforation is repeated mechanical irritation by the relatively fixed catheter tip to the small bowel due to peristalsis. Among the mechanisms, it is the common main factor in the formation of perforation by the catheter, which is limited in the abdomen and which is repeated with intestinal peristalsis. It is also suggested that catheter may cause allergies and cause perforation with intestinal irritation and adhesion (7). It has also been reported that CSF with a high amount of protein will facilitate the formation of perforations by causing adhesions. It has been reported that the insufficiency of the bowel innervation, which causes weakness in the bowel motility, especially in children with spinal system anomalies, may increase the risk of perforation $(8,9)$. Our case had a chronic constipation problem due to myelomeningocele. Although there is no information in the literature about how the length of the catheter in the abdomen affects the risk of perforation, the intra-abdominal peritoneal catheter was quite short in our case (about $10 \mathrm{~cm}$ ). In our case, we think that the intraperitoneal portion of the catheter was too short, causing the catheter to remain in the same localization facilitated the formation of intestinal perforation with recurrent irritations. Shunt dysfunction and infection, which are the abdominal complication of the VP shunt, is defined as a result of examinations. CSF culture, cranial CT, abdominal X-ray, and abdominal CT help with identification. The most frequently isolated organism is Escherichia Coli (9).

Ultrasonography (US) usually provides sufficient information for the evaluation of intraabdominal complications of VP shunt. The most common intraabdominal complication is the pseudocysts, which are usually the liquid loculations formed at the distal end of the shunt catheter and which can be identified by the US. In the evaluation of complications such as catheter migration, the US may be inadequate. The most commonly described type of migration is the protrusion of the catheter tip through the anus. In patients with VP shunting, the location of the catheter tip, as well as whether there is folding in the catheter, should be considered during the radiological evaluation. In our case, no increase in the intraperitoneal fluid was observed, which is usually seen in shunt patients. In the axial CT sections, it was suspected that the catheter tip was in the lumen of the small bowel, and it was confirmed using 3D MPR CT images. In the presented case, the perforation diagnosis was made by abdominal CT. There was no evidence of meningitis. The 
treatment of shunt-dependent gastro-intestinal tract perforation should be individual. Laparotomy should be performed to remove the shunt from the intestine and repair the fistula tract (1). There was no abscess or peritonitis in the abdomen. In cases where these complications are accompanied, laparotomy should be performed because the fistula tract will not close itself. The distal portion of the shunt should be revised with a new catheter. It should be kept in mind that there may be widespread adhesions, as in the case presented, and laparotomy incision should not be kept small.

\section{Conclusion}

The results of abdominal complications of VP shunts are excellent when diagnosed and treated early. Mortality and morbidity decrease significantly with early diagnosis and treatment, especially in asymptomatic bowel perforations. Because of adhesions, the surgical intervention must be performed with laparotomy.

$\overline{\text { Informed Consent: Verbal and written informed consent were obtained }}$ from the patient who participated in this study.

Peer-review: Externally peer-reviewed.

Author Contributions: Surgical and Medical Practices - Ü.B., T.T., I.A.; Concept - Ü.B., A.K.P., M.B.S., S.C..; Design - Ü.B., A.K.P., I.A.; Data Collection and/or Processing - A.K.P., S.C., M.S.; Analysis and/ or Interpretation - T.T., S.Ç., M.S.; Literature Search - T.T., I.A., M.B.S., M.S.; Writing Manuscript - Ü.B., T.T., M.B.S.
Conflict of Interest: No conflict of interest was declared by the authors.

Financial Disclosure: The authors declared that this study received no financial support

\section{References}

1. Sathyanarayana S, Wylen EL, Baskaya MK, Nanda A. Spontaneous bowel perforation after ventriculoperitoneal shunt surgery: case report and a review of 45 cases. Surg Neurol 2000; 54: 388-96.

2. Gupta DK, Dave S. Hydrocephalus. In: Gupta DK, editor. Textbook of Neonatal Surgery. New Delhi: Modern Publishers; 2000. p.434-50.

3. Prusseit J, Simon M, von der Brelie C, Heep A, Molitor E, Volz S, et al. Pediatr Epidemiology, prevention and management of ventriculoperitoneal shunt infections in children. Neurosurg 2009; 45: 325-36.

4. Guillen A, Costa JM, Castello I, Claramunt E, Cardona E. Unusual abdominal complication of ventriculoperitoneal shunt. Neurocirugia 2002; 13: 401-4.

5. Ozveren MF, Kazez A, Cetin H, Ziyal IM. Migration of the abdominal catheter of a VP shunt into the scrotum: case report. Neurol Med Chir 1999; 39: 313-5.

6. Wilson CB, Bertran V. Perforation of the bowel complicating peritoneal shunt for hydrocephalus. Am Surg 1966; 32: 601-3.

7. BrownleeJD, BrodleyJS, SchaeferIK. Colonic perforation byventriculoperitoneal shunt tubing: A case of suspected silicon allergy. Surg Neurol 1998; 49: 21-4.

8. Horning GW, Shillito J Jr. Intestinal perforation by peritoneal shunt tubing: report of two cases. Surg Neurol 1990; 288-90.

9. Ibrahim WA. E. coli meningitis as an indicator of intestinal perforation by V-P shunt tube. Neurosurg Rev 1998; 21: 194-7. 